\title{
Heavy Metal Bioaccumulation by Maize Grown on a Ferralsol Amended with Urban-Based Biosolid Wastes
}

\author{
Emmanuel Ntambi ${ }^{1}$, Muhammad Ntale ${ }^{2}$, John Stephen Tenywa ${ }^{3 *}$ \\ ${ }^{1}$ Department of Chemistry, Faculty of Science, Mbarara University of Science \& Technology, Mbarara, Uganda \\ ${ }^{2}$ Department of Chemistry, College of Natural Sciences, Makerere University, Kampala, Uganda \\ ${ }^{3}$ Department of Agricultural Production, College of Agriculture \& Environmental Sciences, Makerere University, Kampala, \\ Uganda \\ Email: *johntenywa@gmail.com
}

How to cite this paper: Ntambi, E., Ntale, M. and Tenywa, J.S. (2021) Heavy Metal Bioaccumulation by Maize Grown on a Ferralsol Amended with Urban-Based Biosolid Wastes. Journal of Agricultural Chemistry and Environment, 10, 184-195. https://doi.org/10.4236/jacen.2021.102012

Received: February 23, 2021

Accepted: May 5, 2021

Published: May 8, 2021

Copyright $\odot 2021$ by author(s) and Scientific Research Publishing Inc. This work is licensed under the Creative Commons Attribution International License (CC BY 4.0).

http://creativecommons.org/licenses/by/4.0/

\begin{abstract}
Organic waste materials as soil amendments are one of the topical approaches applauded for achieving sustainable agriculture world-over. The objective of this study was to investigate the effect of urban-based biosolid waste (UBBW) application on heavy metals $(\mathrm{Cr}, \mathrm{Cu}, \mathrm{Zn}$ and $\mathrm{Pb}$ ) bioaccumulation by maize (Zea mays L.) plants. A pot experiment was conducted three times, using an acid Ferralsol from Makerere University Agricultural Research Institute, Kabanyolo (MUARIK) in Uganda. Treatments included the application of three types of UBBW, namely sewage, brewery and abattoir, each applied independently at the rates of 0,50 and $100 \mathrm{~g}$ per pot filled with $4 \mathrm{~kg}$ soil. This was equivalent to $0,2.5$ and 5.0 metric tonnes of dry materials per hectare. Phosphorus fertiliser was also applied at $0,0.795$ and $1.591 \mathrm{~g} P$ per pot, equivalent to rates of 0,25 and $50 \mathrm{~kg} \mathrm{P} \mathrm{ha}^{-1}$. The brewery waste applied at rates $\geq 2.5$ t.ha ${ }^{-1}$ and phosphorus at $25 \mathrm{~kg} \mathrm{P} \mathrm{ha}^{-1}$ resulted in shoot $\mathrm{Cu}$ concentrations below the World Health Organisation (WHO) safe limit (73.3 $\left.\mathrm{mg} \cdot \mathrm{kg}^{-1}\right)$; and $\mathrm{Zn}$ slightly above the WHO safe limit $\left(99.4 \mathrm{mg} \cdot \mathrm{kg}^{-1}\right)$. In contrast, the concentrations of chromium in the maize plants were well above the WHO safe limit $\left(2.3 \mathrm{mg} \cdot \mathrm{kg}^{-1}\right)$, irrespective of the applied type of UBBW. Shoot metal bioaccumulation followed the order zinc $>$ copper $>$ chromium, with $\mathrm{Pb}$ being below the detection limit. The safest UBBW was abattoir waste; while the least environmentally suitable was sewage waste. It is clear that irrespective of the type of UBBW, their application to Ferralsol causes less bioaccumulation of $\mathrm{Pb}$ and $\mathrm{Cr}$ in maize plants compared to $\mathrm{Zn}$ and $\mathrm{Cu}$.
\end{abstract}

\section{Keywords}

Lead, Copper, Zinc, Chromium, Zea mays 


\section{Introduction}

Heavy metals often impact human and animal health through unregulated urban waste disposal and when some materials are used for soil productivity amelioration. Although several heavy metals such as $\mathrm{Fe}, \mathrm{Zn}, \mathrm{Cu}, \mathrm{Ni}, \mathrm{Co}$, Mo and $\mathrm{Mn}$ are plant nutrients, others such as $\mathrm{Pb}, \mathrm{Cd}$ and $\mathrm{Hg}$ have no biological value and their consumption even in low concentrations can lead to toxicity and great health risk, particularly through bioaccumulation via the food chain [1] [2]. Hence, proper screening or management of organic resources intended for use in cropping systems is imperative to obviate possible health and environmental calamities.

Among the most burdensome organic wastes whose effective disposal remains unresolved, particularly in urban areas in sub-Saharan Africa, are sewerage effluent and biosolids originating from the surging and unregulated urbanisation and industrialisation [3]. On the other hand, these materials which are naturally endowed with nutrients can be resources for intervening in challenges of soil management, particularly due to declining soil productivity.

Although extensive studies have been done on the microbiology and pathogenicity of these materials [4] [5], empirical information related to the status of heavy metals, their soil loading and plant uptake capacities, and sorption/ desorption patterns is still lacking. The absence of such vital information is a recipe for resource misuse or abuse and risks the lives of unsuspecting farmers and consumers of produce from recipient gardens. Plant heavy metal bioaccumulation studies are particularly critical in understanding and leveraging the natural soil's capacity to attenuate and regulate the concentrations of these metals in plant-available forms.

Alongside this, is the need to monitor how some of the important plant nutrients such as phosphorus, which otherwise exists in plant limiting quantities in organic wastes [6], influence heavy metal behaviour in the soil as well as uptake by plants. The objective of this study, therefore, was to establish the effect of the use of UBBW application on plant bioaccumulation of heavy metals by maize grown on a Ferralsol.

\section{Materials and Methods}

\subsection{Nature of Study}

A pot experiment was conducted at Makerere University Agricultural Research Institute, Kabanyolo (MUARIK) in Uganda. A Ferralsol with characteristics presented in Table 1, was used in this study.

\subsection{Types of Biosolid Wastes Used}

Industrial biosolid wastes (sewage, brewery and abattoir) samples, each of approximately $100 \mathrm{~kg}$, were sourced from Kampala Capital City in central Uganda in January 2014. The sewerage samples were obtained from the National Water and Sewerage Corporation (NWSC) treatment site at Bugolobi; while brewery 
Table 1. Characteristics of three urban biosolid wastes and soil used in the pot study.

\begin{tabular}{|c|c|c|c|c|}
\hline Parameter & Sewage solid waste & Brewery solid waste & Abattoir solid waste & Soil sample \\
\hline \multicolumn{5}{|c|}{$\left(\mathrm{mg} \cdot \mathrm{kg}^{-1}\right)$} \\
\hline $\mathrm{pH}\left(\mathrm{H}_{2} \mathrm{O}\right)$ & 5.9 & 6.0 & 6.9 & 5.4 \\
\hline $\mathrm{CEC}\left(\mathrm{cmolkg}^{-1}\right)$ & $23.9 \pm 1.4$ & $17.6 \pm 0.2$ & $13.6 \pm 0.1$ & $8.7 \pm 0.1$ \\
\hline OM (\%) & $41.5 \pm 3.8$ & $35.0 \pm 1.1$ & $13.0 \pm$ & $2.51 \pm 0.1$ \\
\hline $\mathrm{EC}\left(\mathrm{dSm}^{-1}\right)$ & $10000 \pm 12.0$ & $10000 \pm 8.7$ & $249 \pm 2.3$ & $182.0 \pm 4.9$ \\
\hline $\mathrm{Ca}$ & $8448.0 \pm 46.54$ & $3564 \pm 15.4$ & $50.1 \pm 0.6$ & $6.2 \pm 0.12$ \\
\hline $\mathrm{Mg}$ & $1660.0 \pm 64.81$ & $1132 \pm 10.4$ & $41.7 \pm 0.3$ & $1.55 \pm 0.01$ \\
\hline $\mathrm{K}$ & $1584.0 \pm 4.08$ & $108.9 \pm 0.9$ & $121.7 \pm 0.7$ & $0.85 \pm 0.01$ \\
\hline $\mathrm{Na}$ & $1500.0 \pm 3.45$ & $4500 \pm 5.7$ & $121.4 \pm 1.2$ & $1.31 \pm 0.01$ \\
\hline N (\%) & $1.20 \pm 0.11$ & $2.32 \pm 0.12$ & $13.9 \pm 0.87$ & $0.14 \pm 0.23$ \\
\hline P (Bray 1) & $7200.0 \pm 15.8$ & $14600 \pm 21.4$ & $1076.5 \pm 5.6$ & $2.86 \pm 0.03$ \\
\hline $\mathrm{Cu}$ & $93.0 \pm 3.2$ & $151.5 \pm 4.6$ & $60.9 \pm 1.9$ & $10.0 \pm 1.1$ \\
\hline $\mathrm{Cr}$ & $150.0 \pm 3.7$ & $120.0 \pm 2.3$ & $43.1 \pm 0.8$ & $131.25 \pm 3.0$ \\
\hline $\mathrm{Pb}$ & $45.0 \pm 4.3$ & $15.0 \pm 1.4$ & $0.65 \pm 0.11$ & $12.75 \pm 1.2$ \\
\hline $\mathrm{Zn}$ & $360.0 \pm 10.2$ & $346.0 \pm 6.7$ & $248.0 \pm 4.8$ & $1.34 \pm 0.0$ \\
\hline
\end{tabular}

samples were obtained from the Uganda Breweries Limited (UBL) at Luzira. The slaughter-house (abattoir) samples were collected from Kampala City Abattoir, KCA (former Kampala Meat Packers) in Kampala Central Division.

The biosolid wastes were collected each in a $100 \mathrm{~kg}$ capacity polythene bags, which were pre-cleaned with concentrated spectroscopic nitric acid (about 50 $\mathrm{mL}$ ), and rinsed three times with double distilled water (about $500 \mathrm{~mL}$ ). The biosolid samples were transferred to the screen house at MUARIK where nonorganic materials like stones, pieces of glass and plastic materials were manually sorted out. The remaining biosolid materials were air-dried at room temperature $\left(25^{\circ} \mathrm{C}\right)$ for 5 days.

The dried biosolid wastes were ground into finer particles $(<2.0 \mathrm{~mm})$ using a porcelain mortar and pestle. The crushed solid wastes were saved at room temperature in polythene bags, for laboratory analysis.

\subsection{Experimental Soil}

A bulk soil sample (about $300 \mathrm{~kg}$ ) with a history of active continuous cultivation, but unfertilised for at least 10 years, was collected from MUARIK farm fields. The area was reputed by farmers to be of low productivity. The soil was air-dried on a clean polythene sheet under a shade for 5 days, after screening it for visible materials like roots, litter and stones. After drying, the clods were pulverised using a porcelain mortar and pestle. Three sub-samples were taken for routine soil laboratory analysis and the bulk sample transferred to the screen-house where the pot experiment was set up. 


\subsection{Laboratory Analysis}

The biosolid wastes and soil samples were both analysed for heavy metals ( $\mathrm{Zn}$, $\mathrm{Cu}, \mathrm{Pb}$ and $\mathrm{Cr}$ ), total (for biosolids) and exchangeable (soil) cations (Ca, $\mathrm{Mg}, \mathrm{K}$ and $\mathrm{Na}$ ), organic matter, cation exchange capacity (CEC), $\mathrm{pH}$, electrical conductivity (EC) and Kjeldahl nitrogen using standard procedures [7]. Additionally, the soil sample was analysed for available phosphorus and texture; while the biosolids were analysed for total phosphorus [7].

\subsection{Treatments and Design}

Treatments included three dry biosolid wastes (sewage, abattoir and brewery) applied each at rates of $0,2.5,5.0 \mathrm{t} \cdot \mathrm{ha}^{-1}$ (equivalent to 0,50 and $100 \mathrm{~g}$ biosolid per $4 \mathrm{~kg}$ soil) based on target field nitrogen supply rate. Phosphorus fertiliser (SSP) was also applied at rates of $0,25,50 \mathrm{~kg} \mathrm{P} \mathrm{ha}^{-1}$ (equivalent to $0,0.795$ and $1.591 \mathrm{~g}$ of $\mathrm{P}$ per $4 \mathrm{~kg}$ of soil).

The treatments were laid out in a completely randomised design (CRD), with three replications. The set up was repeated three times, giving a total of $81 \mathrm{ex}-$ perimental units for each biosolid. Five litre capacity plastic pots were used in this experiment and the homogenous mixtures (treatment materials plus soil) were poured in the labelled plastic pots.

\subsection{Experimental Management}

Before planting, soil in each plastic pot was watered with a half-litre of double-distilled water, and left overnight to stabilise. In each pot, five maize (Zea mays L.) seeds of Longe 4 variety were planted as test crop. These were of certified grade seed obtained from FICA Seeds Company Limited, a local seed supplier. The five seeds planted per pot were thinned down to four seedlings at approximately $10 \mathrm{~cm}$ high. The pots were kept weed-free manually and the maize plants harvested for dry mass yield and heavy metal analysis 60 days after planting.

\subsection{Plant Sampling and Analysis}

Two plants per pot were cut at the soil surface level and chopped into small pieces (approximately $1 \mathrm{~cm}$ ) using a stainless steel knife. The samples enveloped in paper bags were oven-dried at $80^{\circ} \mathrm{C}$ for 24 hours. They were desiccator cooled, ground into fine powder and a sub-sample of $0.5 \mathrm{~g}$ from each sample put into Erlmeyer digestion tubes.

The samples were wet-digested using the procedure described by Baker and Amacher [8]. Standard solutions of copper, zinc, chromium and lead were used to calibrate the atomic absorption spectrophotometer (AAS) prior to testing the samples for the heavy metals in each supernatant solution [7].

\subsection{Data Analysis}

Data collected were keyed into a spreadsheet (Microsoft Excel 7.0) and analysed 
using the Statistical Package for Social Scientists (SPSS), version 17.0. Data were checked for normality using the Shapiro-Wilk test. A two-way analysis of variance (ANOVA) was used to generate response means at $\mathrm{p}<0.05$ level of significance.

\section{Results and Discussion}

\subsection{Characteristics of Organic Wastes and Study Soil}

Pre-study characteristics of the three biosolids and soil used in the pot experiment are presented in Table 1 . Sewage sludge was the richest in nutrients and heavy metals profiles among the biosolids considered in this study. This was distantly followed by brewer's waste, and lastly by abattoir waste. All biosolids were consistently richer in all substances than the study soil.

Sewage sludge is known to contain substantial quantities of plant nutrients [9] [10] as well as heavy metals [9] [10] [11]. In fact, the bulk of researches on biosolids (sewage sludge) have more dwelt on its environmental heavy metal loading capacity, with dismal emphasis on soil productivity enhancement [12]. Fortunately, it has been revealed that biosolids application tend to increase microbial activity in soil and this ties up the heavy metals, thus making them biounavailable to plant and soil [13]

The richer endowment of all biosolids wastes with heavy metals than the soil sample (Table 1) was mainly attributable to industrial sources where the metals are used as raw materials. Zinc was the highest in all the three biosolids; conforming to the results obtained by [14] in Nigeria, where the concentrations of heavy metals in abattoir wastewater were within the WHO/USEPA standard limits. The exception was that of Zinc $(0.26 \mathrm{ppm})$ which was above the $\mathrm{WHO} /$ USEPA recommended limits of $0.10 \mathrm{ppm}$, which was fairly higher than the standard recommended by WHO [14] [15]. The inferior presence in nutrient and heavy metal in soil samples compared to the three biosolids (Table 1); with the exception of $\mathrm{Cr}\left(131.25 \pm 3.0 \mathrm{mg} \cdot \mathrm{kg}^{-1}\right)$ which was closely similar to that of sewage solid waste $\left(150.0 \pm 3.7 \mathrm{mg} \cdot \mathrm{kg}^{-1}\right)$ and brewery solid waste $(120.0 \pm$ $\mathrm{mg} \cdot \mathrm{kg}^{-1}$ ), could be attributed to the fact that this soil typically suffers heavy organic matter oxidation and leaching most of the year, owing to the humid condition, coupled by the free drainage properties of this type of Ferralsol [16].

\subsection{Shoot Heavy Metal Concentrations}

\subsubsection{Copper}

The three biosolids had a significant effect $(\mathrm{p}<0.05)$ on the concentration of shoot copper (Figure 1). The differences in maize tissue concentrations were directly related to the inherent $\mathrm{Cu}$ concentrations in the respective biosolids and the rates applied (Table 1). Kelling and others [17] also reported similar results with maize in USA and attributed it to the amounts of sludge added. However, it is also believed that the effect depends on the origin and composition of the waste material, as influenced by the processes of handling and management [10]. 


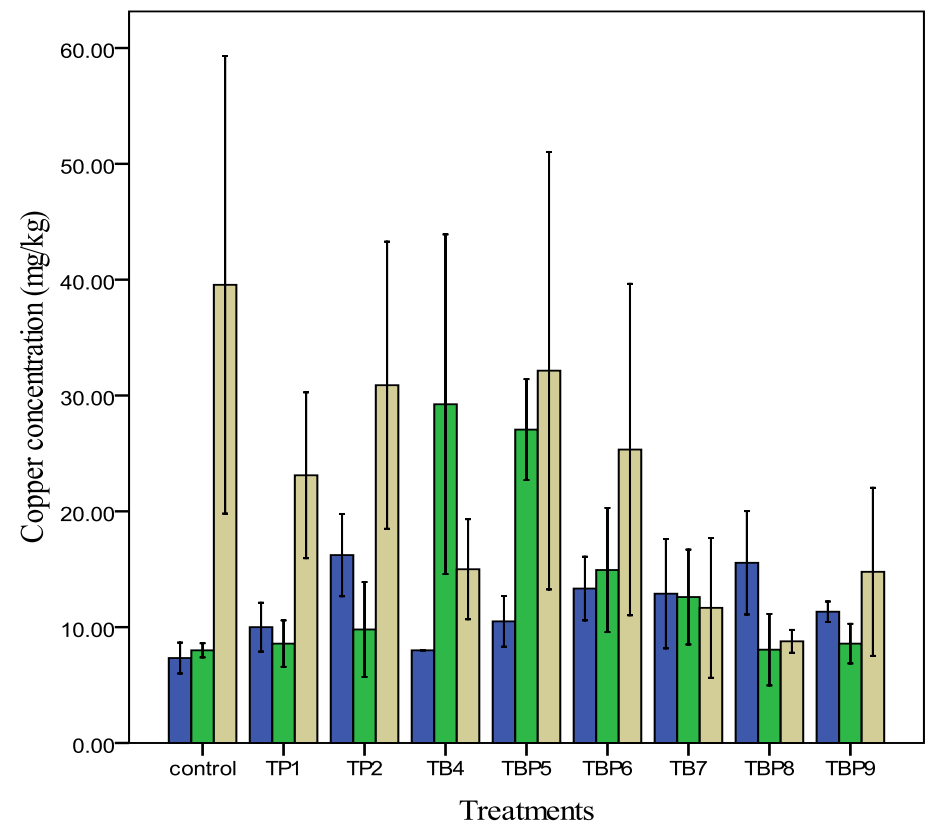

Biosolid

sewage abattoir brewery

Figure 1. Concentration of copper in maize plants for the three biosolids at different rates of application. TP1 $=25 \mathrm{~kg}$ of P ha ${ }^{-1}, \mathrm{TP} 2=50 \mathrm{~kg}$ of P ha- $\mathrm{PB}^{-1}=2.5$ tonnes of biosolid $\mathrm{ha}^{-1}$, TBP5 $=2.5$ tonnes of biosolid ha ${ }^{-1}+25 \mathrm{~kg}$ of $\mathrm{Pha}^{-1}$, TBP6 $=2.5$ tonnes of biosolid $\mathrm{ha}^{-1}+50 \mathrm{~kg}$ of $\mathrm{P} \mathrm{ha}^{-1}$, TB7 $=5.0$ tonnes of biosolid ha ${ }^{-1}$, TBP8 $=5.0$ tonnes of biosolid $\mathrm{ha}^{-1}+25 \mathrm{~kg}$ of $\mathrm{P} \mathrm{ha} \mathrm{a}^{-1}$ and TBP9 $=5.0$ tons of biosolid ha $\mathrm{h}^{-1}+50 \mathrm{~kg}$ of $\mathrm{P} \mathrm{ha} \mathrm{h}^{-1}$.

Although sewage sludge consistently superseded all other biosolids in $\mathrm{Cu}$ concentrations (Table 1), the levels in maize shoots did not vary in matching proportions with application rates probably due to the complexing ability of organic matter and formation of insoluble copper phosphate compounds. Also, plant tissue concentrations remained within the allowable standard limit of 73.3 $\mathrm{mg} \cdot \mathrm{kg}^{-1}[18]$.

Application of $\mathrm{P}$ together with abattoir and brewery biosolids significantly decreased the concentrations of copper in the maize plants (Figure 1). The decrease in plant bioaccumulation of copper was more pronounced at high input rates (Figure 1). Sigh and Swarup [19] reported a decrease in $\mathrm{Cu}$ uptake in a pot study, with application of phosphorus without nitrogen at the rate $45 \mathrm{ppm}$ to wheat, and attributed the effect to alteration of soil $\mathrm{pH}$ which may have reduced the solubility of copper phosphate $\left(\mathrm{K}_{\mathrm{sp}}=1.40 \times 10^{-37}\right)$.

Harpreet [20] observed that application of $\mathrm{P}$ decreased the content of $\mathrm{Cu}$ in exchangeable, amorphous and crystalline oxides, but increased organically bound $\mathrm{Cu}$; implying that bioavailability was affected. This may partly be the reason why plant $\mathrm{P}$ bioaccumulation was affected by application of $\mathrm{P}$. All these observations imply that more specific investigations are still necessary to elucidate the exact mechanisms, which may differ depending on specific soil circumstances.

This finding is useful for soils that are contaminated by copper in the sense that addition of the biosolids would limit the availability of this element to plants, in excess concentration. Thus, plants would grow healthy and eventually 
give good yields.

\subsubsection{Chromium}

The concentration of $\mathrm{Cr}$ in maize plants was also significantly different $(\mathrm{p}<$ 0.05 ) for sewage and abattoir biosolids; but not for brewery biosolids (Figure 2). The differences were also commensurate with the applied biosolids rates and the concentration of chromium in the soil. The insignificant difference could be due to slow mineralisation of brewery biosolids, whose $\mathrm{C} / \mathrm{N}$ ratio was estimated within the range of 17:1 to 12:1 [21]. Thus, changing input rates would not considerably change the concentration of chromium in the amended soil.

The highest tissue concentration of chromium was found in sewage sludge $\left(30.37 \pm 5.46 \mathrm{mg} \cdot \mathrm{kg}^{-1}\right)$, brewer's waste $\left(8.3 \pm 0.97 \mathrm{mg} \cdot \mathrm{kg}^{-1}\right)$ and abattoir waste $\left(20.00 \pm 6.04 \mathrm{mg} \cdot \mathrm{kg}^{-1}\right)$; and the lowest were $12.5 \pm 0.00,5.3 \pm 0.67$ and $4.0 \pm 0.00$ $\mathrm{mg} \cdot \mathrm{kg}^{-1}$, respectively (Figure 2 ). All the concentrations of chromium obtained were above the WHO safe limit of $2.3 \mathrm{mg} \cdot \mathrm{kg}^{-1}$ [18], which is a serious cause for alarm.

The concentration of chromium in the maize plants reduced when the biosolids were jointly applied with phosphorus fertiliser (Figure 2). This could be attributed to possible strong bondage with organic substances, due to formation of insoluble chromium phosphate $\left(\mathrm{K}_{\mathrm{sp}}=2.4 \times 10^{-23}\right)$ as a result of the increasing amounts of phosphorus added fertilizer, which made it unavailable to plants. This is contrary to the work of [22] who used chelating agents and found them to increase the availability of hexavalent chromium.

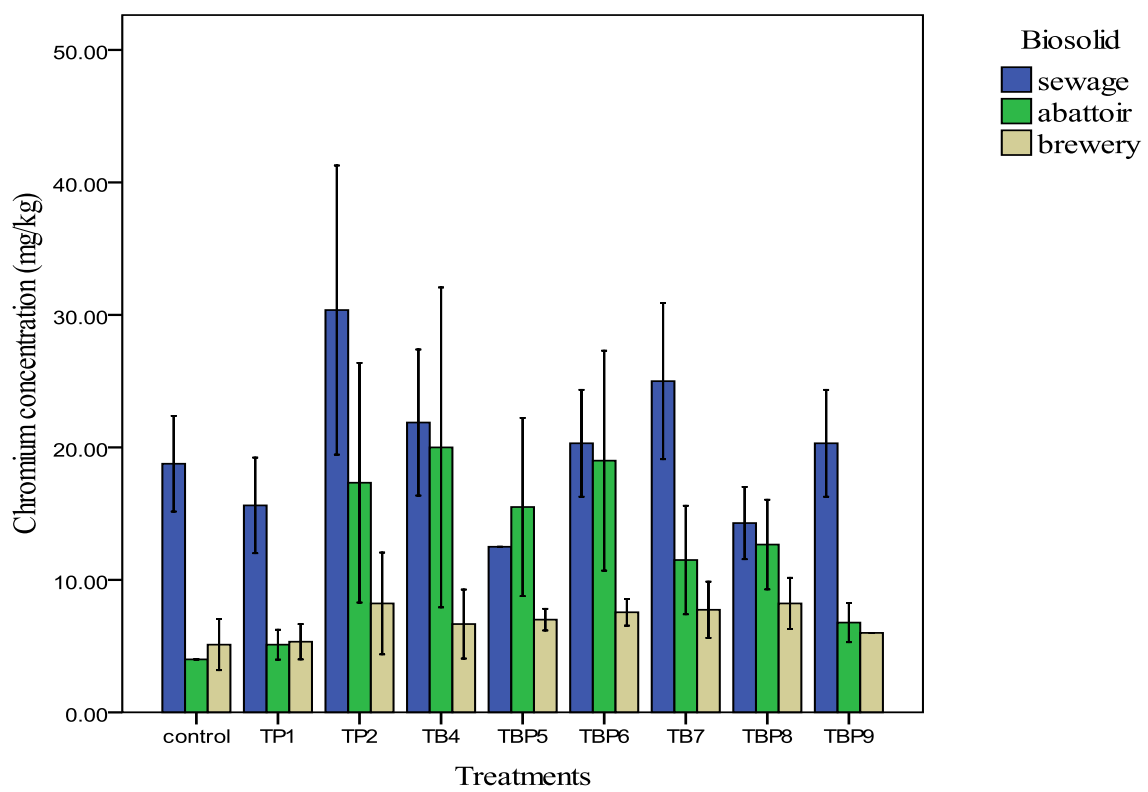

Figure 2. Concentration of chromium in maize plants at 60 days after germination for the three biosolids at the input rates used. TP1 $=25 \mathrm{~kg}$ of $\mathrm{P} \mathrm{ha}^{-1}, \mathrm{TP} 2=50 \mathrm{~kg}$ of P ha ${ }^{-1}$, $\mathrm{TB} 4=2.5$ tonnes of biosolid ha ${ }^{-1}, \mathrm{TBP} 5=2.5$ tonnes of biosolid ha $\mathrm{ha}^{-1}+25 \mathrm{~kg}$ of P ha ${ }^{-1}$, TBP6 $=2.5$ tonnes of biosolid ha $\mathrm{ha}^{-1}+50 \mathrm{~kg}$ of $\mathrm{P} \mathrm{ha} \mathrm{h}^{-1}, \mathrm{~TB} 7=5.0$ tonnes of biosolid ha $\mathrm{ha}^{-1}$, TBP8 $=5.0$ tonnes of biosolid ha $\mathrm{ha}^{-1}+25 \mathrm{~kg}$ of $\mathrm{P} \mathrm{ha}^{-1}$ and TBP9 $=5.0$ tons of biosolid ha $\mathrm{h}^{-1}$ $+50 \mathrm{~kg}$ of $\mathrm{P} \mathrm{ha}^{-1}$. 
A linear increase was observed for shoot bioaccumulation of chromium when the brewery biosolids waste was used (Figure 2). This could be due to the slow mineralisation of biosolids, leading to slow availability of chromium in soluble forms that are easily absorbed by maize plants; a phenomeno code named "time bomb theory" [23]. Therefore, the dynamics of $\mathrm{Cr}$ in the soil is dependent on quantity of biosolids applied, the concentration of heavy metal it is endowed with, its rate of mineralisation properties, as well as the reaction of the soil to the new properties introduced by the biosolids.

The results also suggest that phosphorus fertiliser applied to such soil may enhance the availability of $\mathrm{Cr}$ for plant uptake (Figure 2). This is mainly attributed to the phosphate $\left(\mathrm{PO}_{4}^{3-}\right.$ ) radical (due to strong phosphorus sorption capacity) competing with the hexavalent forms of chromium $\left(\mathrm{HCrO}_{4}^{-}, \mathrm{CrO}_{4}^{2-}\right.$, $\mathrm{Cr}_{2} \mathrm{O}_{7}^{2-}$ ) at binding sites on soil where chromium is displaced, making it phyto available [24].

The limited bioaccumulation of Cr was more with higher biosolids input rates (Figure 2), an indication that application of biosolids coupled with phosphorus fertiliser at high input rates would be strategic for sound environmental management of $\mathrm{Cr}$ bioremediation in soils polluted with chromium.

\subsubsection{Zinc}

The concentration of zinc in maize plants for the three biosolids was found uniquely high for all biosolids, invariably greater than what was found by [17]; and increased with rates of biosolids applied (Figure 3 ). The highest concentrations of zinc were $35.2 \pm 2.04 \mathrm{mg} \cdot \mathrm{kg}^{-1}$ for sewage sludge, $107.2 \pm 16.51 \mathrm{mg} \cdot \mathrm{kg}^{-1}$ for brewery waste, and $41.1 \pm 4.19 \mathrm{mg} \cdot \mathrm{kg}^{-1}$ for abattoir waste. The lowest values were in the order of $17.7 \pm 1.66 \mathrm{mg} \cdot \mathrm{kg}^{-1}$ for sewage sludge, $72.9 \pm 4.02 \mathrm{mg} \cdot \mathrm{kg}^{-1}$ for brewery waste and $30.63 \pm 0.57 \mathrm{mg} \cdot \mathrm{kg}^{-1}$ for abattoir waste, respectively (Figure 3). All the values were far below the WHO safe limit of $99.4 \mathrm{mg} \cdot \mathrm{kg}^{-1}$ [18]; thus bearing no negative attribute when used as a soil input.

Generally, the concentration of $\mathrm{Zn}$ in maize plants demonstrated a progressive linear increase with rates of biosolids applied; also commensurate to the concentration of $\mathrm{Zn}$ in the materials applied. This is a positive relationship for zinc being a micronutrient, which is essential for a range of vital physiological functions in plants [25].

In general, the concentration of zinc in maize plants demonstrated mainly the plateau effect [16] [23] beginning from TBP5 (soil that received treatment (T) of 2.5 tonnes of biosolids (B) per hectare plus 25 kilograms of single super phosphate $(\mathrm{P})$ fertilizer per hectare) onwards when the brewery biosolids were applied together with phosphorus fertiliser (Figure 2). The plateau effect could be attributed to adsorptive materials in sorbent that is, organic matter and amorphous oxides ( $\mathrm{Fe}, \mathrm{Al}$ and $\mathrm{Mn}$ ). As more biosolids amounts are added, the stronger the binding sites of biosolids matrix become dominant over the binding sites in soil. The use of sewage and abattoir biosolids in crop production would thus be good in restricting uptake of zinc by maize plants. Thus, if crops are to 


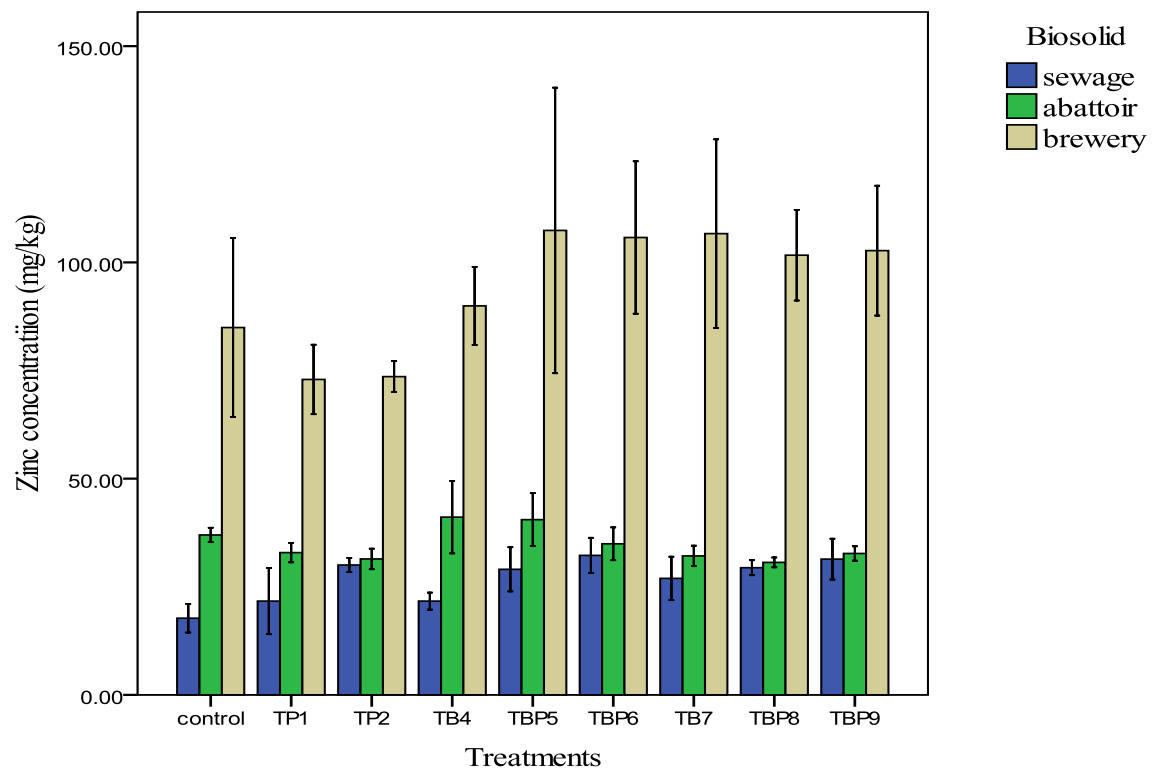

Figure 3. Concentration of zinc in maize plants at 60 days after germination for the three biosolids at different application rates. TP1 $=25 \mathrm{~kg}$ of P ha ${ }^{-1}, \mathrm{TP} 2=50 \mathrm{~kg}$ of P ha ${ }^{-1}$, TB4 $=2.5$ tonnes of biosolid ha ${ }^{-1}$, TBP5 $=2.5$ tonnes of biosolid ha ${ }^{-1}+25 \mathrm{~kg}_{\text {of }} \mathrm{P} \mathrm{ha}^{-1}, \mathrm{TBP} 6=$ 2.5 tonnes of biosolid ha $\mathrm{ha}^{-1}+50 \mathrm{~kg}$ of $\mathrm{P} \mathrm{ha}^{-1}, \mathrm{~TB} 7=5.0$ tonnes of biosolid ha $\mathrm{ha}^{-1}$, TBP8 $=5.0$ tonnes of biosolid ha $\mathrm{ha}^{-1}+25 \mathrm{~kg}$ of $\mathrm{P} \mathrm{ha}^{-1}$ and TBP9 $=5.0$ tons of biosolid ha $\mathrm{h}^{-1}+50 \mathrm{~kg}$ of $\mathrm{P}$ $\mathrm{ha}^{-1}$.

be grown in zinc polluted soil, sewage and abattoir biosolids may be a good choice to use for bioremediation purposes. On the other hand, use of brewery biosolids that interacted with P-fertiliser in crop production would help reduce zinc deficiency normally experienced in plants [26].

For the abattoir biosolids, the concentration of zinc in maize plants decreased when the treatments of TBP5 to TBP9 were used (Figure 3). The decrease was also due to the effect of the adsorptive tendencies in the organic matter of the biosolids, which complexed zinc and limited its availability for plant uptake. Phosphorus fertiliser could also have contributed to the decrease in Zn availability by precipitating the nutritive cation to insoluble zinc phosphate $\left(\mathrm{K}_{\mathrm{sp}}=9.0 \times\right.$ $10^{-33}$ ). The implication of the decreasing trend on agricultural cropping systems is that the micronutrient would be less available with increasing input rates.

\subsection{Sequence of Heavy Metal Bioaccumulation}

The effect of biosolids together with phosphorus fertilizer application on the order of maize plant bioaccumulation of heavy metals was in the order of zinc $>$ chromium $>$ copper for sewage sludge, zinc $>$ copper $>$ chromium for brewery waste and zinc $>$ copper $>$ chromium for abattoir waste. The order similarity of brewery and abattoir biosolids seems to be related to both $\mathrm{Zn}$ and $\mathrm{Cu}$ being plant nutrients; as opposed to $\mathrm{Cr}$ which is not. This order of bioaccumulation of these nutrients may be due to the charge-to-radius ratios of the metals and the organic matter content of soil, which predisposes metals to adsorption; the higher its value the greater the adsorption [27]. Also, the higher the organic matter in the 
soil the greater the adsorption, particularly for copper [26].

The higher bioaccumulation of zinc could have been due to it being adsorbed electrostatically, which makes it participate easily in exchange reactions. In contrast, the low uptake of chromium could be due to its high charge-to-radius ratio, which enhanced its sorption strength to the sorbent surface sites. A similar conclusion was made by [27], whereby chromium was found to be strongly sorbed and retained when the same soil was subjected to the same treatment conditions under a laboratory setting.

\section{Conclusion}

Application of biosolids (sewage, brewery and abattoir wastes) considerably augments the bioaccumulation of $\mathrm{Cu}, \mathrm{Cr}$ and $\mathrm{Zn}$; with or without supplementation with $\mathrm{P}$. However, application of $\mathrm{P}$ enhances the rate of bioaccumulation of $\mathrm{Zn}$ (brewery) and Cr (sewage) heavy metals. As such, sewage and abattoir bear great potential for $\mathrm{Cu}$ and $\mathrm{Zn}$ bioremediation but subject to further investigations. All values of copper determined in the maize plants are below the WHO safe limit $\left(73.3 \mathrm{mg} \cdot \mathrm{kg}^{-1}\right)$; while those of chromium are above the WHO safe limit $\left(2.3 \mathrm{mg} \cdot \mathrm{kg}^{-1}\right)$ for all the three biosolids used. All zinc contents in sewage and abattoir are, below the WHO safe limit $\left(99.4 \mathrm{mg} \cdot \mathrm{kg}^{-1}\right)$; while that of the brewery waste is above this limit. The combined effect of biosolids and $\mathrm{P}$ application on the order of maize plant bioaccumulation of heavy metals is in the order of zinc $>$ chromium $>$ copper for sewage sludge, zinc $>$ copper $>$ chromium for brewery waste and zinc $>$ copper $>$ chromium for abattoir waste.

\section{Acknowledgements}

The authors wish to acknowledge the financial assistance from the Belgian Technical Cooperation (BTC) and Mbarara University of Science and Technology and the technical assistance rendered by the Soil Laboratory of the Department of Agricultural Production, College of Agriculture and Environmental Studies, Makerere University.

\section{Conflicts of Interest}

The authors declare no conflicts of interest regarding the publication of this paper.

\section{References}

[1] Jordao, C.P., Nascentes, C.C., Cecon, P.R., Fontes, R.L.F. and Pereira, J.L. (2006) Heavy Metal Availability in Soil Amended with Composted Urban Solid Wastes. Environmental Monitoring and Assessment, 112, 309-326. https://doi.org/10.1007/s10661-006-1072-y

[2] Duruibe, J.O., Ogwuegbu, M.O.C. and Egwurugwu, J.N. (2007) Heavy Metals Pollution and Human Biotoxic Effects. International Journal of Physical Sciences, 2, 112-118.

[3] Alloway, B.J. and Ayers, D.C. (1993) Chemical Principles of Environmental Pollu- 
tion. Blackie Academic and Professional, London, 291 p.

[4] Oun, A., Kumar, A., Harrigan, T., Angelakis, A. and Xagoraraki, I. (2014) Effects of Biosolids and Manure Application on Microbial Water Quality in Rural Areas in the US (A Review). Water, 6, 3701-3723. https://doi.org/10.3390/w6123701

[5] Network, C.W. (2015) Risks Associated with Application of Municipal Biosolids to Agricultural Land in Canadian Context. Literature Review. Canadian Municipal Water Consortium, Ryerson University, Toronto. http://www.cwn-rce.ca/assets/resources/pdf/McCarthy-Risks-Biosolids-2015.pdf

[6] Palm, C.A. and Rowland, A. (1997) Chemical Characterization of Plant Quality for Decomposition. In: Cadish, G. and Giller, K.E., Eds., Driven by Nature: Plant Litter Quality and Decomposition, CAB International, Wallingford, 379-394.

[7] Page, A.L., Miller, R.H. and Keeney, D.R.E. (1982) Methods of Soil Analysis. Part II. 2nd Edition, American Society of Agronomy, Madison, 803.

[8] Baker, D.E. and Amacher, M.C. (1982) Nickel, Copper, Zinc and Cadmium. In: Page, A.L., Miller, R.H. and Keener, D.R., Eds., Methods of Soils Analysis. Part II, 2nd Edition, American Society of Agronomy, Soil Science Society of America, Madison, 323-363.

[9] U.S. Environmental Protection Agency (1993) 40 CFR Part 503 Standards for the Use and Disposal of Sewage Sludge Subpart B Land Applications (503.13-Pollutant Limits) 58FR9387.

[10] U.S. Environmental Protection Agency (2011) Water: Sewage Sludge (Biosolids). http://water.epa.gov/polwater/wastewater/treatment/biosolids/index.cfm

[11] UN-Habitat (2008) Global Atlas of Excreta, Wastewater Sludge, and Biosolids Management: Moving forward the Sustainable and Welcome Uses of a Global Resource. 632 .

[12] Al-Musharafi, S.K., Mohamond, I.Y. and Al-Balury, S.N. (2013) Heavy Metal Pollution from Treated Sewage Effluents. APCBEE Procedia, 5, 344-348.

https://doi.org/10.1016/j.apcbee.2013.05.059

[13] Sastre, L., Vicente, M.A. and Lobo, M.C. (1996) Influence of the Application of Sewage Sludges on Soil Microbial Activity. Bioresource Technology, 57, 19-23. https://doi.org/10.1016/0960-8524(96)00035-1

[14] Nasiru, A., Osakwe, C.E., Lawal, I.M. and Chinade, A.U. (2016) Assessment of Physical Parameters and Heavy Metals in Gombe Abattoir Wastewater. American Journal of Engineering Research (AJER), 5, 64-69.

[15] Ediene, V. and Iren, O. (2017) Impact of Abattoir Effluents on the pH, Organic Matter, Heavy Metal Levels and Microbial Composition of Surrounding Soils in Calabar Municipality. Asian Journal of Environment and Ecology, 2, 1-10. https://doi.org/10.9734/AJEE/2017/33341

[16] Dick, D.P., Gonclaves, C.N., Dalmolin, R.S.D. and Neto, L.M. (2005) Characteristics of Soil Organic Matter of Different Brazilian Ferralsols under Native Vegetation as a Function of Soil Depth. Geoderma, 124, 319-333. https://doi.org/10.1016/j.geoderma.2004.05.008

[17] Kelling, K.A., Keeney, D.R., Walsh, L.M. and Ryan, J.A. (1977) A Field Study of the Agricultural Use of Sewage Sludge: III. Effect on Uptake and Extractability of Sludge-Borne Metals. Journal of Environmental Quality, 6, 352-358. https://doi.org/10.2134/jeq1977.00472425000600040004x

[18] WHO (1996) Permissible Limits of Heavy Metals in Soil and Plants. World Health Organization, Geneva. 
[19] Sigh, D.V. and Swarup, C. (1982) Copper Nutrition of Wheat in Relation to Nitrogen and Phosphorus Fertilization. Plant and Soil, 65, 433-436. https://doi.org/10.1007/BF02375066

[20] Harpreet, K. (2014) Transformation and Availability of Copper to Wheat (Triticum aestivum L.) as Influenced by Phosphorus Fertilization. Environmental Science.

[21] Mingchu, Z. (2015) Using Spent Brewery Grain in the Alaska Compost Pile. The University of Alaska Fairbanks Cooperative Extension Service in Cooperation with the United States Department of Agriculture.

http://www.alaska.edu/titleIXcompliance/nondiscrimination

[22] Monalisa, M. and Kumar, P.H. (2012) Effect of Chelate-Assisted Hexavalent Chromium on Physiological Changes, Biochemical Alterations, and Chromium Bioavailability in Crop Plants-An in Vitro Phytoremediation Approach. Bioremediation Journal, 16, 147-155. https://doi.org/10.1080/10889868.2012.687414

[23] Silveira, M.L.A., Alleoni, L.R.F. and Guilherme, L.R.G. (2003) Biosolids and Heavy Metals in Soils. Science Agricola (Piracicaba, Braz.). 60, 793-806. https://doi.org/10.1590/S0103-90162003000400029

[24] Pakade, V.E., Tavengwa, N.T. and Madikizela, L.M. (2019) Recent Advances in Hexavalent Chromium Removal from Aqueous Solutions by Adsorptive Methods. RSC Advances, 9, 26142-26164. https://doi.org/10.1039/C9RA05188K

[25] Tsonko, T. and Cebola, L.F.J. (2012) Zinc in Plants-An Overview. Emirates Journal of Food and Agriculture, 24, 322-333.

[26] Alloway, B.J. (1995) Heavy Metals in Soils. Blackie Academic and Professional, London, 7-39. https://doi.org/10.1007/978-94-011-1344-1

[27] Ntambi, E., Tenywa, J.S. and Ntale, M. (2020) Sorption and Desorption Phenomena of Urban Biowaste-Based Heavy Metals by a Ferralsol. Journal of Agricultural Chemistry and Environment, 9, 13-26. https://doi.org/10.4236/jacen.2020.91002. 